\title{
GIMNASTIKOS IR AKROBATIKOS PRATYBU POVEIKIS ŠUOLININKŲ SU KARTIMI PUSIAUSVYROS GEBĖJIMAMS
}

\author{
Roma Aleksandravičiene் $\dot{1}^{1,2}$, Marina Grigorjeva ${ }^{3}$, Loreta Stasiulevičiené2 \\ Kristina Zaičenkoviené $\dot{2}^{2}$, Laimutis Škikas ${ }^{2}$, Ramunė Liaugminiene் ${ }^{1}$ \\ Lietuvos žemès ūkio universitetas ${ }^{1}$, Lietuvos kūno kultūros akademija ${ }^{2}$, Kauno technologijos \\ universitetas $^{3}$, Kaunas, Lietuva
}

Roma Aleksandravičienè. Biomedicinos mokslų daktarè. Lietuvos žemès ūkio universiteto Kūno kultūros ir sporto centro asistentė, Lietuvos kūno kultūros akademijos Gimnastikos ir šokio katedros lektorè. Mokslinių tyrimų kryptys: aerobinio ir anaerobinio pajėgumo bei bioenergetikos greitoji ir lètoji adaptacija dèl fizinių krūvių poveikio; treniruotès proceso kontrolè ir kompleksinis vertinimas.

\section{SANTRAUKA}

Judejimas visada susijęs su greičio pokyčiais, t. y. pagreičiais, kurie yra judančiu žmogaus organizmo daliu dirgikliai. Žmogaus koordinacija ir orientacija erdvèje priklauso nuo pusiausvyros, regos, judèjimo analizatoriu ir ju treniruotumo. Tai ypač aktualu sportineje veikloje. Egzistuoja tiesioginis ryšis tarp sportinio meistriškumo ir vestibulinès funkcijos. Lvairiu šaku sportininku vestibulinès funkcijos atsparumo išraiška esti skirtinga, kadangi sporto šaku specifika nevienodai veikia vestibulini analizatoriu (Авижонене, 1993; Катуков и Шорин, 1990). Daugelis lengvosios atletikos rungčiu reikalauja geros judesiu koordinacijos. Ypač tai aktualu atliekant šuolius su kartimi. Todèl šiuo tyrimu bandyta atskleisti, koki poveiki jaunuju šuolininku su kartimi pusiausvyros somatinèms reakcijoms turi gimnastikos ir akrobatikos pratybos. Tyrimo tikslas — nustatyti gimnastikos ir akrobatikos pratybu poveiki jaunuju šuolininku su kartimi pusiausvyros gebëjimams. Buvo tiriamos dvi 12-15 m. amžiaus vieneriu—treju metu sportinio stažo šnolininku su kartimi grupès: pirma - gimnastikos ir akrobatikos pratybas $(n=8)$ lankantys tris mènesius vienq karta per savaite (2007 metais) ir keturis menesius vienq karta per savaite (2008 metais); antra — nelankantys gimnastikos ir akrobatikos pratybu $(n=8)$. Tirtu šuolininku stabilografijos testo rezultatai palyginti su 12-15 m. jaunuju sprinteriu rodikliais $(n=8)$.

Pusiausvyros somatiniu reakciju dydis buvo tiriamas taikant aktyvuji otolitinès reakcijos mégini $O_{5}$ ir 10-ies apsisukimu maksimaliuoju greičiu i abi puses (penkis kartus kairèn ir penkis - dešinèn) testa vestibulinei funkcijai ¿̀vertinti (Rušas, Bagočiūnas, 1999).

Visi pusiausvyros rodikliai atlikus aktyvuji otolitinès reakcijos mègini, 10-ties apsisukimu kairèn ir dešinèn testa bei stabilografijos testa buvo geresni gimnastikos ir akrobatikos pratybas lankančiu šuolininku su kartimi negu to paties amžiaus sprinteriu ir šuolininku su kartimi, nelankančiu tokio pobūdžio pratybu. Vadinasi, gimnastikos ir akrobatikos pratybos teigiamai veikia jaunuju šuolininku su kartimi vestibuline funkcija ir pusiausvyra.

Raktažodžiai: šuoliai su kartimi, gimnastika, akrobatika, pusiausvyra, vestibuline funkcija.

\section{IVADAS}

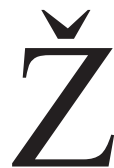
mogaus pusiausvyra priklauso nuo gebos integruoti daugybinę sensorinę informacija ir reguliuoti daugiasegmentès biomechaninès sistemos padèti. Pusiausvyros valdymas, norint išlaikyti kūno padèties stabilumą ir garantuoti reikiamą kūno segmentų orientaciją, paremtas griaučių raumenų ir nervų sistemos sąveika. Griaučių raumenų komponentai, lemiantys pusiausvyros stabilumą, yra judesių amplitude, stuburo lankstu- mas, raumenų mechaninès savybès, biomechaninè kūno segmentų tarpusavio sąsaja (Juodžbalienè, Muckus, 2006). Daugeli metu pusiausvyros pratybos buvo taikomos reabilitacijos metu. Dabar vis dažniau jos yra taikomos, norint išvengti traumu sportinėje veikloje (Anderson, Behm, 2005; Hrysomallis, 2007).

Daugelis tyrejjų mano, kad kūno pusiausvyros erdveje išsaugojimą lemia vestibulinis analizatorius, 
kuris aktyviai dalyvauja raumenų tonuso reguliavimo sistemos veikloje. Žmogus tam tikru gyvenimo laikotarpiu geba geriau išmokti specialius judesius, tačiau geriausiai jų išmokstama būnant jauno amžiaus ir gana ilgai išlieka jų nekartojant. Vaikui augant gerèja tokios jų fizinès savybès kaip greitumas, jèga, tikslumas, koordinacija ir ištvermè. Didejja gebejjimas greitai priimti sprendimus, ir tai labai reikalinga atliekant sudètingos koordinacijos judesius. Žmogaus koordinacija ir orientacija erdvèje priklauso nuo vestibulinio, regos, judejjimo analizatoriu ir jų treniruotumo. Tai ypač aktualu sportinejje veikloje. Sistemingas treniravimasis tonizuojamai veikia vestibulini analizatorių. Pastebèta, kad kuo aukštesnè sportininko kvalifikacija, tuo atsparesnis vestibulinis analizatorius. Mokslininkai nustate tiesioginį ryši tarp sportinio meistriškumo ir vestibulinès funkcijos atsparumo. Daugybe refleksu, kurie atsiranda dirginant mažai treniruotų sportininkų vestibulini analizatoriu, gali neigiamai paveikti visą organizmą, kartu ir sportini rezultatą. Refleksai, atsiradę dirginant vestibulini analizatorių, prastina net ir nesudètingu judesių atlikimo kokybę, ir tai lemia raumenu tonuso pasiskirstymo pokytis. Ivairiu šakų sportininkų vestibulinès funkcijos atsparumo išraiška esti skirtinga, kadangi sporto šakų specifika nevienodai veikia vestibulini analizatoriu (Авижонене, 1993; Катуков и Шорин, 1990). Daugelis lengvosios atletikos rungčių reikalauja geros judesiu koordinacijos. Ypač tai aktualu atliekant šuolius su kartimi, todèl šiuo tyrimu bandyta atskleisti, kaip jaunujų šuolininkų su kartimi pusiausvyros somatines reakcijas veikia gimnastikos ir akrobatikos pratybos.

Tyrimo tikslas - nustatyti gimnastikos ir akrobatikos pratybų poveiki jaunujų šuolininkų su kartimi pusiausvyros gebejjimams.

\section{Uždaviniai:}

1. Nustatyti gimnastikos ir akrobatikos pratybu poveiki šuolininkų su kartimi pusiausvyros gebejjimams atliekant aktyvuji otolitinès reakcijos mègini.

2. Nustatyti gimnastikos ir akrobatikos pratybu poveiki šuolininkų su kartimi pusiausvyros gebejimams atliekant 10-ties apsisukimų maksimaliojo greičio testą $i$ abi puses.

3. Nustatyti gimnastikos ir akrobatikos pratybu poveiki jaunujų šuolininkų su kartimi pusiausvyros gebejjimams atliekant stabilografijos testą bei palyginti su gimnastikos ir akrobatikos pratybų nelankančių šuolininku su kartimi ir sprinterių analogiškais gebejjimais.

\section{TYRIMO METODIKA}

Tiriamieji. Buvo tiriamos dvi 12-15 m. amžiaus vieneriu_ - trejų metų sportinio stažo šuolininkų su kartimi grupès: pirma - gimnastikos ir akrobatikos pratybas $(n=8)$ lankantys tris mènesius vieną kartą per savaitę (2007 metais) ir keturis ménesius vieną kartą per savaitę (2008 metais), antra - nelankantys gimnastikos ir akrobatikos pratybu $(n=8)$. Abieju grupių respondentai treniravosi penkis kartus per savaitę. Tirtų šuolininkų stabilografijos testo rezultatai buvo palyginti su $12-15 \mathrm{~m}$. jaunuju sprinterių rodikliais $(\mathrm{n}=8)$.

Tyrimo metodai. Pusiausvyros somatinių reakcijų dydis buvo tiriamas taikant aktyvuji otolitinès reakcijos mėgini $\mathrm{OR}_{5}$ (penkis kartus kairèn ir penkis - dešinèn) ir 10-ies apsisukimų maksimaliojo greičio testą $\mathfrak{i}$ abi puses vestibulinei funkcijai ivvertinti (Rušas, Bagočiūnas, 1999).

Atlikdami $\mathrm{OR}_{5}$ mėgini, tiriamieji užrištomis akimis turèjo pasilenkti pirmyn $90^{\circ} \mathrm{kampu}$ (delnus padejję ant kelių), paskui jiems buvo liepiama apsisukti pristatomuoju žingsniu penkis kartus $180^{\circ}$ per sekundę greičiu kairèn. Atlikęs apsisukimus, tiriamasis vèl turèjo grį̌ti i pagrindinę stovèseną. Po triju poilsio minučiu tie patys judesiai buvo kartojami i̇ dešinę pusę. Registruoti šie rodikliai: pusiausvyros atgavimo trukmè (t) (1 lent.) ir griuvimo (svyravimo) laipsnis grižus ił pagrindinę stovėseną (2 lent.).

Tiriamajam stovint užrištomis akimis $1 \mathrm{~m}$ skersmens rato viduryje buvo vertinama vestibulinè funkcija. Tiriamieji turèjo atlikti dešimt apsisukimu kairèn, o po triju poilsio minučiu — tiek pat dešinèn. Tiriamajam buvo taikomi šie reikalavimai: 1) apsisukti maksimaliuoju greičiu; 2) sava-

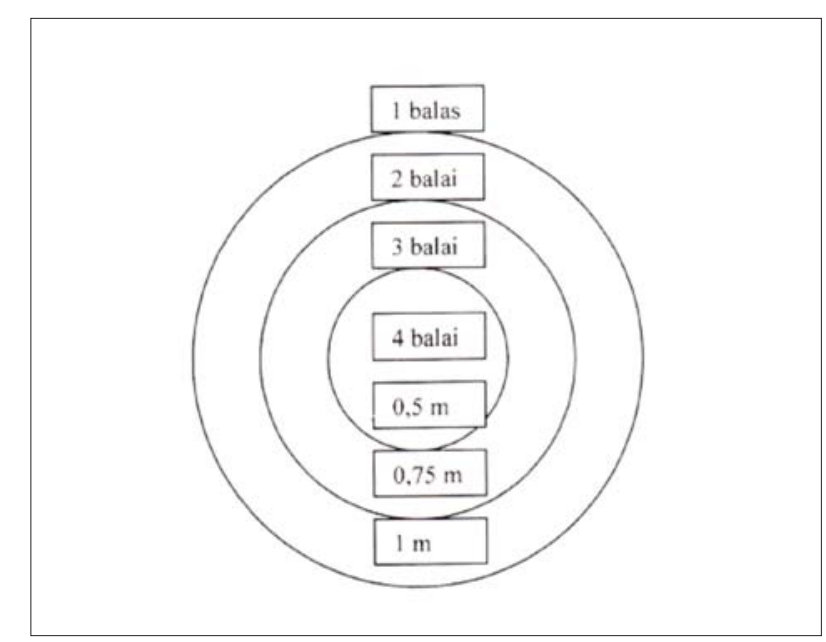

1 pav. Vestibulinès reakcijos tyrimo schema 
1 lentelè. Pusiausvyros atgavimo po apsisukimų trukmè

\begin{tabular}{|l|c|}
\hline Pusiausvyros atgavimo trukmé, s & Ivertinimas balais \\
\hline Nuo 0 iki 5 & 1 \\
\hline Nuo 6 iki 15 & 2 \\
\hline Nuo 16 iki 25 & 3 \\
\hline Nuo 26 ir daugiau & 4 \\
\hline
\end{tabular}

2 lentelè. Griuvimo (svyravimo) laipsnis po apsisukimų

\begin{tabular}{|l|c|}
\hline Požymiai & $\begin{array}{c}\text { Svyravimo laipsnis } \\
\text { (balais) }\end{array}$ \\
\hline Išlaiko pagrindinės stovėsenos padėtị & 1 \\
\hline Nevalingi galvos judesiai, svyravimas & 2 \\
\hline Stiprus svyravimas, griuvinėjimas & 3 \\
\hline Visiškas pusiausvyros netekimas & 4 \\
\hline
\end{tabular}

rankiškai skaičiuoti apsisukimus; 3) neišeiti iš rato vidurio. Vertinama 4 balų sistema (1 pav.).

Pusiausvyros gebejimams vertinti buvo naudojama stabilogramos registravimo iranga LIBRA (,Elektronic Balance Board“), susidedanti iš stabilografinès platformos ir kompiuterinès registravimo bei duomenų vertinimo programos. Pusiausvyros gebejimai vertinti tiriamiesiems stovint ant stabilografinès platformos, pėdas sustačius lygiagrečiai, atliekant 1 min trukmès pusiausvyros išlaikymo užduotis: atmerktomis ir užmerktomis akimis išlaikyti pusiausvyrą frontalioje plokštumoje pratimą kartojant tris kartus. Registruoti šie rodikliai: 1) bendras plotas - santykiniais vienetais išreikštas stabilografinès kreivès plotas tiriamajam nukrypus i kairę ar i dešinę puses iki išoriniu linijų; 2) išorinis plotas - santykiniais vienetais išreikštas stabilografinès kreivès plotas tiriamajam nukrypus i kairę ar į dešinę pusę už išorinių linijų; 3) laikas išoriniame plote — sekundėmis išreikštas nuokrypio laikas ị kairę ir ił dešinę pusę nuo išorinių linijų, grižimo ị takelị laikas - sekundèmis išreikštas laikas iki išorinių linijų iš maksimalaus nuokrypio ị kairę ir į dešinę.

Statistinè analizè. Pateikiami aritmetiniai vidurkiai $(\bar{x})$ ir aritmetinio vidurkio paklaida $(S \bar{x})$. Statistinis skirtumo patikimumas buvo apskaičiuojamas naudojant Studento $t$ testą. Visi skaičiavimai atlikti naudojant programini paketą Statistica for Windows.

\section{REZULTATAI}

Ivertinus svyravimo laipsni po apsisukimu, tirtų grupių rodikliai abiejų testavimų metu statistiškai reikšmingai skyrèsi $(\mathrm{p}<0,05)$ : gimnastiką ir akrobatiką lankančiu jaunuju šuolininku su kartimi apsisukimu kairèn rodiklis pirmo testavimo metu siekè $1,88 \pm 0,16$, antro $-1,68 \pm 0,14$ balo, o nelankančių tiriamujų pirmo testavimo metu $-2,65 \pm 0,21$, antro $-2,55 \pm 0,19$ balo. Po apsisukimų dešinèn gimnastiką ir akrobatiką lankančiu grupeje pirmo testavimo metu rodiklis siekè $2,00 \pm 0,15$, antro $-1,80 \pm 0,13$ balo. Nelankančiu papildomu pratybų tiriamuju grupeje rodikliai pirmo testavimo metu sieké 2,63 $\pm 0,07$, antro $-2,53 \pm 0,06$ balo. Po antro testavimo abieju grupių rodikliai pagerejo, tačiau skirtumas nebuvo statistiškai reikšmingas $(\mathrm{p}>0,05)$.

Atlikus apsisukimus kairèn, greičiau pusiausvyra atgavo gimnastikos ir akrobatikos pratybas lankantys šuolininkai - pirmo testavimo metu per $5,01 \pm 0,71 \mathrm{~s}$, antro - per 4,52 $\pm 0,68 \mathrm{~s}$, tuo tarpu nelankantys pirmo testavimo metu pusiausvyrą atgavo per $10,85 \pm 2,44 \mathrm{~s}$, antro - per $0,25 \pm 2,34 \mathrm{~s}$ $(\mathrm{p}<0,05)$. Po apsisukimų dešinèn išryškèjo ta pati rodiklių kitimo tendencija - statistiškai patikimai $(p<0,05)$ greičiau pusiausvyrą atgavo gimnastikos ir akrobatikos pratybas lankantys šuolininkai su kartimi - pirmo testavimo metu per $6,36 \pm 0,88 \mathrm{~s}$, antro - per 5,85 $\pm 0,85 \mathrm{~s}$, o nelankantys — pirmo testavimo metu per $10,57 \pm 0,51 \mathrm{~s}$, antro - per $10,26 \pm 0,48 \mathrm{~s}$ (5 pav.) Abiejų testuotu grupių pusiausvyros atgavimo rodikliai antro testavimo metu pagerèjo, tačiau skirtumas nebuvo statistiškai reikšmingas $(p>0,05)$.

Tyrimo rezultatai rodo, kad laikas, per kuri tiriamieji turejo atlikti apsisukimus, abiem testavimo atvejais statistiškai patikimai $(\mathrm{p}<0,05)$ buvo geresnis papildomas gimnastikos ir akrobatikos pratybas lankančiu jaunujų šuolininku su kartimi: kairèn - lankančiuju laikas pirmo testavimo metu siekè vidutiniškai $11,17 \pm 0,92 \mathrm{~s}$, antro - 10,65 $\pm 0,88 \mathrm{~s}$, nelankančių - pirmo testavimo metu $-14,17 \pm 0,67 \mathrm{~s}$, antro $14,02 \pm 0,62 \mathrm{~s}$; dešinèn - lankančių laikas pirmo testavimo metu $-11,06 \pm 1,59 \mathrm{~s}$, antro $10,47 \pm 1,47 \mathrm{~s}$, nelankančiu pirmo testavimo metu $-16,44 \pm 1,59 \mathrm{~s}$, antro $-15,8 \pm 1,46 \mathrm{~s}$ (2 pav.).

Abiejų tiriamuju grupių šio rodiklio pokytis per metus nebuvo statistiškai reikšmingas $(p>0,05)$.

Specialiuju pratybu poveiki vestibuliniam analizatoriui akivaizdžiai rodo rodikliai, gauti ivertinus nukrypimus nuo centro sukimosi metu. Abiejose tirtose grupèse geresni rodikliai užfiksuoti atliekant apsisukimus kairèn. Papildomas gimnastikos ir akrobatikos pratybas lankančiu sportininkų rodiklis (pasisukimų kairèn) pirmo testavimo metu $-2,00 \pm 0,03$, antro $-2,08 \pm 0,05$ balo, tuo tarpu nelankančiu pirmo testavimo metu $-1,60 \pm 0,27$, antro $-1,65 \pm 0,29$ balo. Atlikus apsisukimus dešinèn, papildomas praty- 
2 pav. 10 apsisukimų trukmė

Pastaba. * - statistiškai patikimas grupių rodiklių skirtumas $(\mathrm{p}<0,05)$

3 pav. Stabilografijos testo atsimerkus bendro nuokrypio ploto i kairę ir i dešinę rodikliai mingas rodikliu skirtumas tarp gimnastikos bei akrobatikos pratybas lankančių ir nelankančių tiriamųjų; $\Delta$ - statistiškai reikšmingas rodikliu skirtumas tarp gimnastikos ir akrobatikos pratybas lankančiu tiriamuju ir sprinteriu.

4 pav. 1 min stabilografijos atsimerkus testo - išorinio ploto i kairę ir i dešinę rodikliai
Pastaba. * - statistiškai reikš-
Pastaba. * - statistiškai reikšmingas rodiklių skirtumas tarp gimnastikos ir akrobatikos pratybas lankančių ir nelankančių tiriamujų; ${ }^{\circ}$ - statistiškai reikšmingas rodiklių skirtumas tarp gimnastikos bei akrobatikos pratybų nelankančių tiriamujų ir sprinteriu.
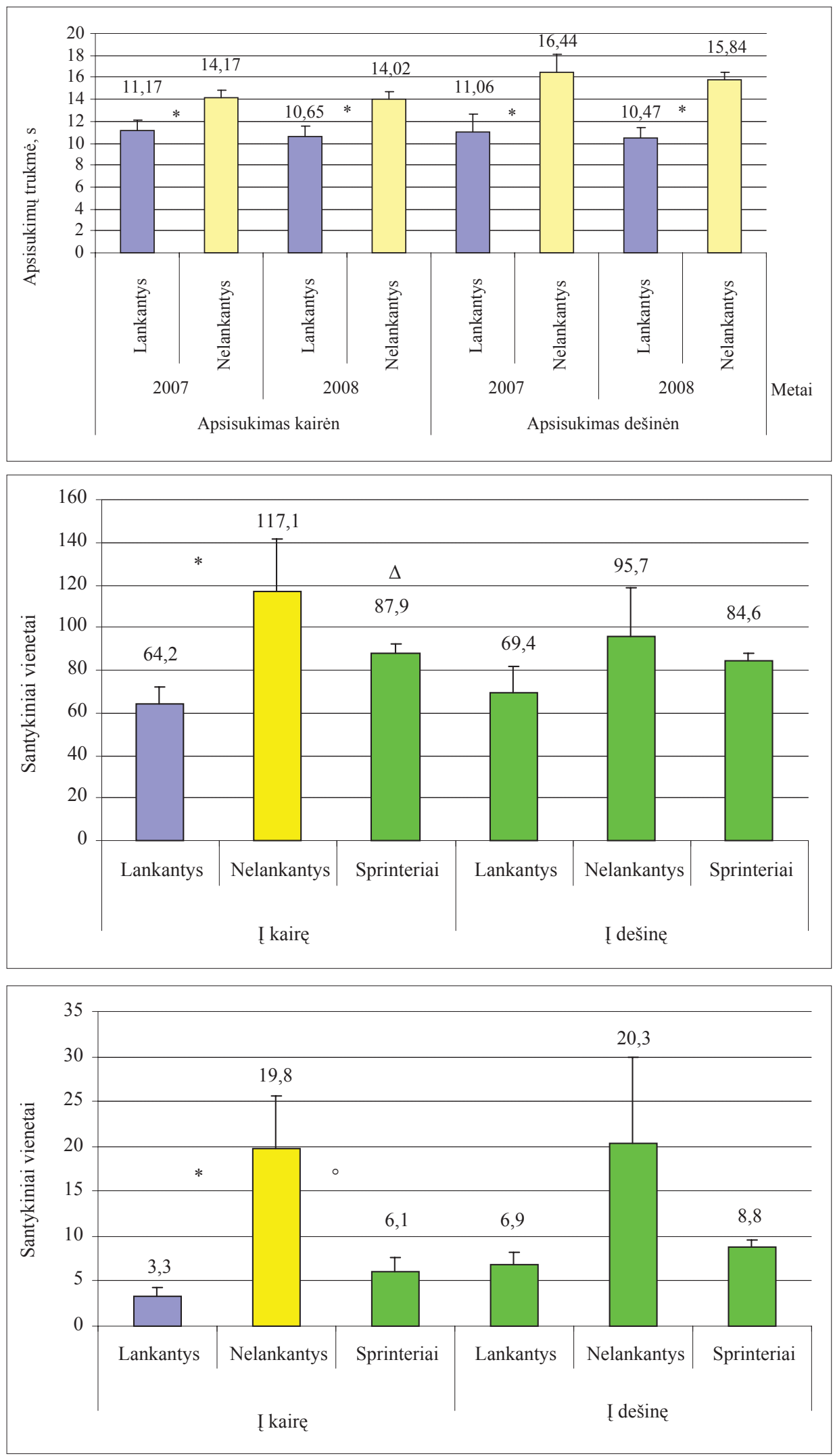

bas lankančių sportininkų rodiklis pirmo testavimo metu $-1,40 \pm 0,45$, antro $-1,60 \pm 0,55$

Lyginant skirtingų lengvosios atletikos specializacijų (šuolių su kartimi ir sprinterių) tiriamujų (stabilografijos testo atsimerkus) bendro nuokrypio ploto į kairę ir į dešinę rodiklius ( 3 pav.) nustatytas statistiškai reikšmingas $(\mathrm{p}<0,05)$ skirtumas. Nuokrypio ploto ị kairę rodikliai geresni buvo gimnasstatistiškai reikšmingas. 

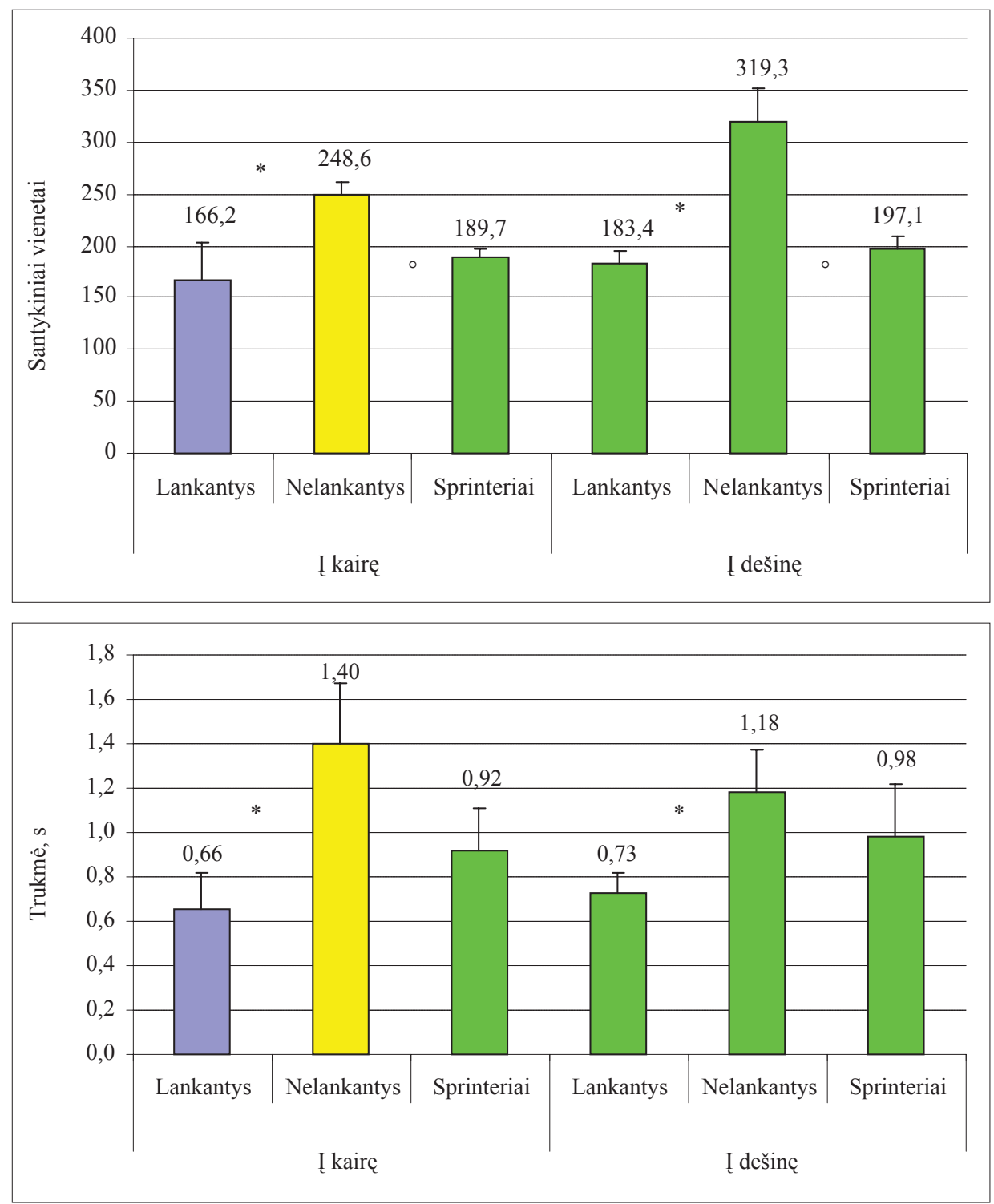

5 pav. Stabilografijos testo užsimerkus, bendro nuokrypio ploto ị kairę ir ị dešinę - rodikliai

Pastaba. * - statistiškai reikšmingas rodikliu skirtumas tarp gimnastikos ir akrobatikos pratybas lankančiu ir nelankančiu tiriamujų; ${ }^{\circ}$ - statistiškai reikšmingas rodikliu skirtumas tarp gimnastikos ir akrobatikos pratybų nelankančių šuolininkų su kartimi ir sprinteriu.

6 pav. 1 min testo stabilografijos atsimerkus - grị̌imo laiko ị takelị iš maksimalaus nuokrypio ị kairę ir dešinę - rodikliai

Pastaba. * - statistiškai reikšmingas rodikliu skirtumas tarp gimnastikos ir akrobatikos pratybas lankančiu ir nelankančiu tiriamuju. tikos ir akrobatikos pratybas lankančių sportininku grupejje. Stebint bendro nuokrypio ploto į dešinę pusę rodiklius, gimnastikos ir akrobatikos pratybas lankančių tiriamuju jie buvo taip pat geresni, tačiau statistiškai reikšmingai nesiskyrè $(p>0,05)$.

Atlikus 1 min stabilografijos testą atsimerkus (nuokrypio už išorinių linijų) nustatyta, kad lengvaatlečių, nelankančių papildomų pratybų, geriausi rodikliai buvo jaunujų sportininkų, lankančių gimnastikos ir akrobatikos pratybas (4 pav.). Tačiau statistiškai reikšmingas skirtumas nustatytas vertinant nuokrypi už išorinių liniju kairèn pusèn $(\mathrm{p}<0,05)$.

Nustatyta, kad bendro nuokrypio ploto i kairę pusę užsimerkus rodikliai buvo geresni visose tiriamuju grupèse. Geriausių rezultatu pasiekè papildomas pratybas lankantys šuolininkai su kartimi (5 pav.).

Vertinant pusiausvyros gebejimus pagal buvimo išoriniame plote atsimerkus trukmę, geriausi rodikliai nustatyti gimnastikos ir akrobatikos pratybas lankančių lengvaatlečių grupejje ir statistiškai reikšmingai $(\mathrm{p}<0,05)$ skyrėsi nuo rodiklių, gautu papildomu pratybų nelankančių lengvaatlečių bei sprinteriu grupių. Gimnastikos ir akrobatikos pratybas lankančių lengvaatlečiu geresni rodikliai buvo vertinant nuokrypio laiką i kairę pusę 2,6 s (i dešinę - 4,3 s), tuo tarpu kitų tiriamuju grupiu geresni rodikliai - vertinant nuokrypio laiką i dešinę: sprinterių nuokrypio laikas i kairę pusę - 6,3 s (i dešinę - 5,8 s), lengvaatlečiu, nelankančiu papildomu pratybu - atitinkamai 8,1 ir $6,4 \mathrm{~s}$.

Palyginus buvimo išoriniame plote užsimerkus ir buvimo išoriniame plote atsimerkus trukmę, nustatytas statistiškai reikšmingas rodiklių skirtumas $(p<0,05)$ visose tiriamuju grupése: gimnastikos ir akrobatikos pratybas lankančiu lengvaatlečiu nuokrypio laiko ị kairę pusę rodikliai - 14,0 s (i dešinę - 15,2 s), nelankančių papildomų pratybų 
lengvaatlečiu —atitinkamai $21,5,26,2 \mathrm{~s}$, sprinterių $-17,7$ ir $17,4 \mathrm{~s}$.

Grižimo laiko į takeli iš maksimalaus nuokrypio ị kairę ir dešinę rodikliai gimnastikos ir akrobatikos pratybas lankančiu šuolininku buvo statistiškai reikšmingai $(\mathrm{p}<0,05)$ geresni negu nelankančiu ir nedaug $(p>0,05)$ geresni negu sprinteriu (6 pav.).

\section{REZULTATŲ APTARIMAS}

Daugelio šakų sportininkams pusiausvyros išlaikymas yra labai svarbus, nors kultivuojant vienas jis dominuoja atliekant judesius standartinemis sąlygomis tiksliai numatoma tvarka, kitas - kūnui judant besikeičiančiomis sąlygomis. Optimali somatosensorinių sistemų sąveika lemia žmogaus kūno segmentu stabilumo ir padėties kontrolę (Danusevičiūtè ir kt., 2007). Žinoma, kad įvairiu judesiu atlikimo tikslumas priklauso nuo vestibulinio analizatoriaus atsparumo. Vestibulinio analizatoriaus dirginimo metu atsiradę refleksai prastina net ir nesudètingų judesiu atlikimo kokybę, ir tai lemia atsiradęs raumenu tonuso pasiskirstymo pokytis. Sistemingas treniravimasis tonizuojamai veikia vestibulini analizatorių. Kuo aukštesnè sportininko kvalifikacija, tuo atsparesnis vestibulinis analizatorius. Regimosios informacijos stoka sukelia pusiausvyros, kūno segmentu padèties reguliavimo, atsako i aplinkos dirgikliu pokyčius (Kristinsdottir et al., 2001; Juodžbalienė, Muckus, 2006). Mokslininkai teigia (Latash, 1998; Guerraz et al., 2001; Peterka, 2002), kad pirminé pusiausvyrą koreguojanti funkcija tenka regai, o proprioceptorių informacija palaikant pusiausvyrą yra mažiau reikšminga. Tai patvirtina ir šio tyrimo rezultatai: visų tirtu grupių stabilografijos testo atmerktomis akimis rodikliai buvo kur kas mažesni nei užmerktomis. Sensorika aktyviai dalyvauja motorikos valdymo procese: koreguoja judesiu valdymo aukščiausių lygių komandas, dalyvauja suvokiant atliekamus judesius ir aplinką, stimu- liuoja refleksinius judesius. Regimoji informacija taip pat priklauso nuo vestibulinio ir regos analizatoriaus tarpusavio sąveikos, ir ši informacija svarbi tada, kai pusiausvyros užduočių metu stabilizuojama galva ir akys (Danusevičiūtè ir kt., 2007). Rega galima identifikuoti objektus ir jų judèjimą aplinkoje, ji teikia informaciją apie aplinką, kūno segmentų padètị ir judejjimą aplinkos, kitų kūno dalių atžvilgiu.

Apibendrinant šio tyrimo rezultatus galima konstatuoti, kad gimnastikos ir akrobatikos pratybas lankančių šuolininkų su kartimi pusiausvyros atgavimo trukmė yra daug trumpesnè. Gimnastikos ir akrobatikos pratimai teigiamai veikia žmogaus raumenų tonusą ir jo reguliavimą. Gauti rezultatai rodo, kad specifiniai vestibuliniai krūviai teigiamai veikia pusiausvyros atgavimo trukmę bei svyravimo laipsni ( $\mathrm{OR}^{5}$ mėginys), užduočiu diferencijavimą (10 apsisukimų testas) bei pusiausvyros rodiklių gerẻjimą (stabilografija).

\section{IŠVADOS}

1. Atlikus aktyvuji otolitinès reakcijos mėginį nustatyta, kad gimnastikos ir akrobatikos pratybas lankančių šuolininkų su kartimi pusiausvyros atgavimo trukmè yra daug trumpesnè, o svyravimo laipsnis mažesnis negu nelankančių šių pratybų.

2. Užduočių diferencijavimo 10-ties apsisukimų kairèn ir dešinèn maksimaliuoju greičiu testo metu geresnių rezultatų pasiekè gimnastikos ir akrobatikos pratybas lankantys jaunieji šuolininkai su kartimi.

3. Visi pusiausvyros rodikliai (testuojant stabilografu) buvo geresni gimnastikos ir akrobatikos pratybas lankančių šuolininkų su kartimi negu to paties amžiaus tokio pobūdžio pratybų nelankančių sprinterių ir šuolininkų su kartimi. Gimnastikos ir akrobatikos pratybos teigiamai veikia jaunujų šuolininkų su kartimi vestibulinę funkciją ir pusiausvyra.

\section{LITERATŪRA}

Anderson, K., Behm, D. G. (2005). The impact of instability resistance training on balance and stability. Sports Medicine, 35 (1), 43-53.

Daniusevičiūtè, L, Emeljanovas, A., Poderys, J. ir kt. (2007). 11-14 metų amžiaus vaikų pusiausvyros ir sensomotorinių rodikliu kaita. Sporto mokslas, 3 (49), 29-35. Guerraz, M., Gianna, C. C., Burchill, P. M. et al. (2001). Effect of visual surrouding motion on body sway in a threedimensional environment. Perception \& Psychophysics, 63 (1), 47-58.

Hrysomallis, C. (2007). Relationship between balance ability, training and sports injury risk. Sports Medicine, 37 (6), 547-556.

Juodžbaliene, V., Muckus, K. (2006). The influence of the degree of visual impairment on psychomotor reaction and equilibrium maintenance of adolescents. Medicina, 
$42(1), 49-56$.

Kristinsdottir, E. K., Fransson, P. A., Magnusson, M. (2001). Changes in postural control in healthy elderly subjects are related to vibration sensation, vision and vestibular asymmetry. Acta Otolaryngologica, 212, 700706 .

Latash, M. L. (1998). Neurophysiological Basis of Movement. USA: Human Kinetics. P. 267.

Peterka, R. J. (2002). Sensorimotor integration in human postural control. Journal of Neurophysiology, 88 (3), $97-118$.
Rušas, R., Bagočiūnas, S. (1999). Sporto treniruotès poveikis vestibulinèms somatinèms reakcijoms. Ugdymas. Kūno kultūra. Sportas, 2 (31), 53-56.

Авижониене, Г. М. (1993). Повыление эфективности спортивной тренировки гандболистов путём направленного развития устойчивости вестибулярного анализатора. Минск.

Катуков, Б. В., Шорин, Г. А. (1990). Роль вестибулярного анализатора в двигательной деятельности спортсмена. Омск.

\title{
THE EFFECT OF GYMNASTICS AND ACROBATICS EXERCISES ON BALANCE ABILITIES OF POLE-VAULTERS
}

\author{
Roma Aleksandravičiené $\dot{~}^{12}$, Marina Grigorjeva ${ }^{3}$, Loreta Stasiulevičiené2 $\dot{2}^{2}$ Kristina Zaičenkoviené ${ }^{2}$, \\ Laimutis Škikas ${ }^{2}$, Ramunè Liaugminiené ${ }^{1}$ \\ Lithuanian University of Agriculture ${ }^{1}$, Lithuanian Academy of physical Education ${ }^{2}$, Kaunas University \\ of Technology, Kaunas, Lithuana
}

\begin{abstract}
All movements are involved in the changes of speed, which are stimulus of all parts of the human organism. Certainly human coordination and feeling of space depend on vestibular, visual, motional analysers and their development. It is very important in sports activity. It has been established that technical skills are directly related to resistance of vestibular function. The aspects of resistance of vestibular function in various kinds of sport are different, because vestibular analyser is irregularly impacted by the specificity of various branches of sport (Авижонене, 1993; Катуков, Шорин, 1990). Many events in track-and-field athletics need good coordination of motions. Particulary this is important in pole vault event, therefore we attempted to know if gymnastics and acrobatics training affects vestibular somatic reactions of young pole vault athletes.

The aim of the research was to establish the influence of gymnastics and acrobatics classes on balance abilities of pole vault athletes. A group of young $(12-15$ year-old) pole vault athletes $(n=16)$ participated in this experiment. Their mean training experience in pole vault event was two years. All the subjects were divided in two groups: the first group of athletes attended gymnastics and acrobatics classes once a week, the second group trained under usual conditions. The obtained results of pole vault jumpers were compared with the indexes of young sprinters of the same age who trained under usual conditions. The amount of vestibular somatic reactions was assessed by using the sample of active otolithic reactions and the test to estimate their vestibular function - 10 rotations with maximum speed to both sides (five times to the right, five times to left side) (Rušas, Bagočiūnas, 1999). The results of this study showed that all the indexes in first group were better for athletes who attended gymnastics and acrobatics classes.

We suggest that gymnastics and acrobatics training is very effective for pole vault athletes and has a positive effect on their vestibular function and balance.
\end{abstract}

Keywords: pole vault, gymnastics, acrobatics, balance, vestibular function.

Gauta $2008 \mathrm{~m}$. rugsèjo $30 \mathrm{~d}$.

Received on September 30, 2008
Roma Aleksandravičienè

Lietuvos kūno kultūros akademija

(Lithuanian Academy of Physical Education)

Sporto g. 6, LT-44221 Kaunas

Lietuva (Lithuania)

Tel +37068636488

E-mail romanellagrande@gmail.com 